\title{
Entrepreneurs' endogenous attributes necessary for small enterprise success in Vhembe rural areas, South Africa
}

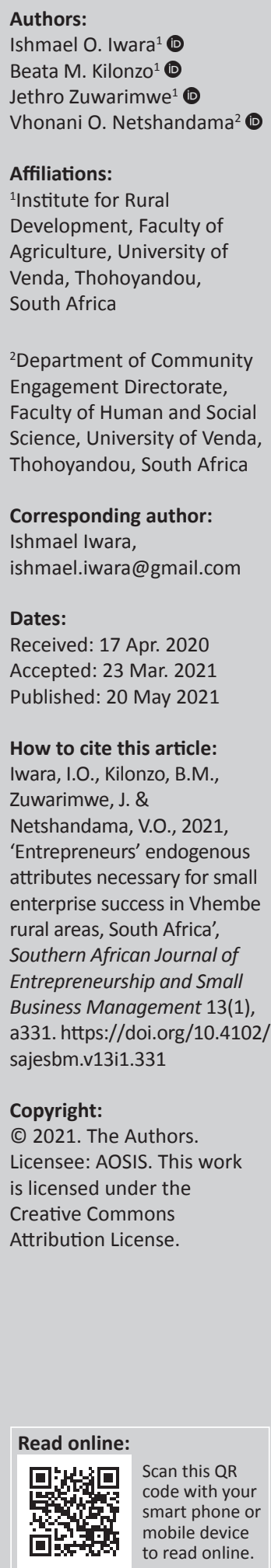

Background: Enterprises in South Africa, especially in rural areas, continue to fail, despite the continuous support from government. A key contributing factor is that most enterprises' support is channelled to exogenous factors without recognising their endogenous predisposition as well.

Aim: This article isolated entrepreneurs' endogenous attributes which if complemented with exogenous support could spur enterprise success.

Setting: This study focussed on addressing enterprise failure in rural areas of Vhembe; however, the findings can be applied in other areas in South Africa and beyond.

Methods: A sample of 81 participants was drawn using the snowball sampling technique. The qualitative data gathered from this sample using a semi-structured questionnaire were then analysed through Atlas-ti v8 from which 49 items were isolated. This informed a quantitative component that entailed the development of a 5-point Likert scale for data collection in the second phase of the study, where, subsequently, 280 respondents were engaged. The Principal Component Analysis was used to reduce the data dimension of 49 items to five principal components which accounted for $68.794 \%$ of the total variance.

Results: The five principal components isolated were bridging-networks (38.044), self-belief (15.802), risk-awareness (6.144), resilience (4.532) and non-conforming (4.271). Further analysis was performed on data collected from 83 participants who met the $50 \%$ performance threshold using the linear regression. Bridging-network is the most important endogenous success factor in the study area, followed by nonnon-conformist risk-awareness, resilience and self-belief.

Conclusion: Results conform to grassroots realities, thus, a framework anchored on this was developed to support enterprises grassroots enterprises.

Keywords: endogenous attributes; enterprise failure; rural area; success factors; grassroots realities.

\section{Introduction}

Small scale enterprises' failure in South Africa has been a topical issue for years. Trends of enterprise performance in the country indicate that growth of local enterprises, especially small, micro and medium enterprises (SMMEs), has declined in the recent years (Asah, Fatoki \& Rungani 2015; Douglas et al. 2017; Madzimure 2020; Rabie, Cant \& Wiid 2016). This has positioned the country to be at par with countries with the high enterprise failure rates in the world. According to the Small Enterprise Development Agency (SEDA 2014/15), the failure rate of newly established enterprises stands at $75 \%$. Nheta et al. (2020) suggested a framework for improving entrepreneur preparedness as three out of four enterprises collapse within 3 years of their establishment. The resultant socio-economic predicament poses serious challenges to the country's employment prospects. Indeed, South Africa is considered as having the highest youth unemployment in the world (Stat SA 2018), and the high unemployment issue has been linked directly to SMMEs' failure in the country (Iwara et al. 2019; Nyamunda \& Van Der Westhuizen 2018; Tshabalala 2014). Evidence from developed economies, such as USA, Singapore, Japan and China also indicates that SMMEs development is the backbone of economic growth and contributes significantly to overall employment in these countries (Musa \& Semasinghe 2013).

A close look at SMMEs failure in South Africa shows that there is underutilisation of certain endogenous predisposing factors to successful venturing (Iwara 2018; Nkondo 2017). It seems that 
enterprise support in the country emphasises more on exogenous factors, such as access to finance, security and the market. Endogenous factors have not been given ample attention in small business research, even though in some countries they have been found to complement exogenous factors effectively. According to Blume and Sargent (2015), a holistic entrepreneurial activity is that which successfully harnesses both exogenous and endogenous components in its framework, although there is a strong belief that a significant component of SMMEs' failure is attributable to constraints from the exogenous environment, especially finance (Agbenyegah 2013; Agwa-Ejon \& Mbohwa 2015; Asongu \& Odhiambo 2019; Cant \& Wiid 2013; Chimucheka \& Rungani 2011; Kato \& Tsoka 2020; Moos \& Sambo 2018). It becomes particularly worrisome when the majority of SMMEs with access to various forms of exogenous support still fail (Sustainable Development Consortium 2007; Madichie, Mpiti \& Rambe 2019; Malebana 2017; Ramukumbasup et al. 2011). Despite this, the role of endogenous factors towards the success of SMMEs can be the missing link in their poor performance in South Africa.

A study in rural areas of the Limpopo province by Ladzani and Netswera (2009) established that nearly $80 \%$ of the SMMEs perceived access to finance as the main challenge to small enterprises. This observation is consistent with studies conducted in other areas of South Africa, and this is noted by scholars, such as Hansen et al. (2012), Agwa-Ejon and Mbohwa (2015), Moos and Sambo (2018). More often, the support offered to SMMEs by the government and other stakeholders focussed more on exogenous factors that include finance and access to market. The Department of Trade and Industry (DTI), for instance, ensures access to small business support mainly in the form of funding and information, strengthening small businesses' advocacy as well as enhancing effective service and monitoring impact (DTI 2007). The continual benefit from exogenous factors, especially, finance is now in doubt because of the high failure rate of those who have access to finance. For instance, Abor and Quartey (2010) contended that endogenous attributes, such as ability to identify suitable product for a particular market, formalisation of an enterprise and proper record keeping, are of equal importance to the operation of a successful small enterprise, as access to finance. This narrative conforms with Mmbengwa (2013), Nkondo (2017) and Iwara (2018) arguments that failure to consider endogenous attributes contributes significantly to enterprise failure in South Africa. Based on these arguments, it can be assumed that entrepreneurs' endogenous factors play a significant role towards enterprises' success as exogenous factors do; however, these have not been given much attention. Entrepreneurship support systems and entrepreneurs have positioned exogenous factors as crucial for enterprise success, neglecting the place of endogenous factors and this is a concern that should be addressed urgently.
This article established the endogenous attributes that complement exogenous attributes in enhancing small enterprises' success. These attributes were identified from local entrepreneurs who have managed small enterprises successfully in rural areas. The study's focus on successful enterprises is with the assumption that they can better inform, from experience, whose attributes are required not only to drive, but guarantee SMMEs success. These attributes emanate from grassroots enterprises in the rural areas, hence, the belief that they can inform small enterprises capacity building in the same context. This article is organised as follows - firstly, an overview of enterprise development and endogenous attributes associated with it is explained, then the methodological approach which entails the composition of the participants, sampling techniques, data collection approaches and analytical methods is discussed and lastly, the findings along with interpretations are expatiated.

\section{Enterprise development in South Africa}

Cognisant of the fact that entrepreneurial activities, especially, those of small enterprises are critical to improving economic growth in the country (Lekhanya \& Mason 2014), the DTI was introduced as an integrated institution for the promotion of entrepreneurship and small enterprises development (DTI 2007). This was amongst other integral reforms by the post1994 government to reintegrate the marginalised into the economy, create job opportunities and poverty reduction through entrepreneurship (White Paper on Local Government, Republic of South Africa [RSA] 1998). As earlier mentioned, the DTI was designed to enhance access to small business support of various forms and monitor their impact. The DTI Black Business Supplier Development Programme, Small Enterprise Finance Agency (SEFA) and the Industrial Development Corporation (IDC) were structures created to support the mandate. Subsequently, the National Youth Development Agency (NYDA), the SEDA, the Centre for Small Business Promotion (CSBP), the Ntsika Enterprise Promotion Agency and the Khula Enterprise Finance Limited were also initiated (SA Economic Development Department 2014).

In the Limpopo province, where the current study was conducted, Ladzani (2010) explained that the provincial government was involved in the discussion process that led to the White Paper on the National Strategy for the Development and Promotion of Small Business in the country. Taking into account that SMMEs are pivotal for leveraging unemployment and the economic inequality the country is grappling with, the province joined efforts with other provinces to support the National Small Business Amendment Act of 2004. This provides, amongst others, a favourable business environment, market accessibility, flexible policies and regulations as well as security for small businesses development. In the context of Limpopo, two key structures were established - the Limpopo Economic Development Enterprise (LEDE) that seeks to develop and promote a suitable enterprise sector by assisting with 
investment opportunities for grassroots entrepreneurs (LEDE 2006) and the Trade and Investment Limpopo (TIL) that is responsible for the development of a network for establishments that intend to expand its market operations within the country and beyond (TIL 2006). Several other initiatives through the local municipal governments were rolled out in an effort to scale up enterprises; however, despite these efforts, small enterprises' failure rates continue unabated. Based on the synthesised literature, several efforts made to promote enterprises are anchored on exogenous factors, with very little attention paid to the contribution of entrepreneurs' endogenous factors. This gap could account for the failure, therefore, leaving room for researchers to explore the role of endogenous factors in business success.

\section{Endogenous attribute}

Entrepreneurs' endogenous attribute is a well conceptualised construct in Schumpeter's innovation theory of entrepreneurship and economic development. Endogenous attributes refer to the internal traits of an entrepreneur (ed. Schumpeter 1934). It is the inner features, morals and mental qualities distinctive to an individual which influence their motives, actions and performance (Ha et al. 2014; Ummah \& Gunapalan 2012). Schumpeter opines that endogenous factors are also key drivers that determine positive change in entrepreneurial activities and bring success. Innovation, as one of the drivers, is at the centre of economic change and it brings about significant creativity (ed. Schumpeter 1934); however, this is not sufficient to guarantee success unless well harnessed. The basic components of innovation, such as invention, diffusion and development of ideas are its identified intrinsic values. The advancement of these values in an entrepreneurial environment makes some entrepreneurs successful whilst others fail even if given equal market opportunity (Chu, Benzing \& McGee 2007; De Faria Cosme 2012; Krejci, Strielkowski \& Čabelková 2015; ed. Schumpeter 1934; Stefanovic et al. 2010). In agreement with Schumpeter, Sledzik (2013) averred that entrepreneurs' success depends on their ability to combine new goods and services, be innovative, exploit the latest method of production, find suitable markets and sources of supply as well as interact with new organisations in their activities. Given these arguments, the place of endogenous factors in business venturing cannot be undermined, thus, sole reliance on exogenous support cannot guarantee successful enterprises.

In Brazil, Djankov et al. (2007) established that ability to relate and collaborate with family, be smart and the ability to harness opportunities timeously are important endogenous attributes entrepreneurs should possess to thrive. In addition, entrepreneurs' attitude that reflects motivation, capacity to identify and pursue an opportunity, as well as ability to add value to economic goods were mentioned. A comparative study in USA and Norway isolated positive mindset and the ability to align to the environment as key entrepreneurs' endogenous attributes (Mongia 2013). Shrewdness, a profitdriven mindset, strict management, high level of professionalism and willing to explore new opportunities were also discussed in the literature on American small enterprises (Buchanan 2015; Acs, Szerb \& Autio 2015).

Chuang and Liao (2010) emphasised the ability to source and hire skilled workers, as well as manage and regulate their activities as ensuring efficiency. These views are consistent with Krejci et al. (2015), when they examined the factors influencing the performance of enterprises in ICT, in the Czech Republic; they found that decisions on the nature of investment and earnings-employee ratio based on skills and knowledge were paramount in enhancing the success of small and medium enterprises. In a similar study carried out in Malaysia, Rose, Kumar and Yen (2006) investigated the dynamics of entrepreneurs' success factors and established that understanding of market systems and customer relationship are prime attributes that influence performance. The identification of different endogenous factors responsible for business success, across studies and countries indicates that the entrepreneurship landscape is far from being straightforward. This makes it essential to locate area-specific endogenous attributes for capacity building as what is appropriate in one environment may not apply to another.

To emphasise on the need for context-specific research on enterprises, Ummah and Gunapalan (2012) examined factors influencing entrepreneurial success in Sri Lanka, and mentioned that innovation and determination are key endogenous factors to successful enterprises. Sledzik (2013), Siriwan et al. (2013) and Ha et al. (2014) emphasised innovative thinking, creative mindset, ability to work exceptionally hard and risk-taking as influential. Some of these results conform with the findings of studies made in Thailand, Laos and Bangladesh which identify with working exceptionally hard, good communication, marketing skills, self-evaluation and the understanding of modern technologies as important endogenous entrepreneurial attributes (Ha et al. 2014). Murugesan and Jayavelu (2017) and Baluku, Matagi, Musanje, Kikooma and Otto (2019) highlighted the roles of optimism, personality and perceived control as well as self-efficacy. In another study, carried out in Kenya, Maina (2012) revealed the ability to relate personal ideas with what is existing in the market as essential. Similarly, Bensassi and Jabbour (2017) asserted that skills and experience are key endogenous attributes responsible for the success of enterprises run by returning migrants in Egypt. In addition, the International Financial Corporation (IFC) (Abouzaid 2018), Belz (2015) and Al-Youm (2015) established family bonds and social ties as endogenous attributes responsible for good enterprise performance. Swai (2014) mentioned the ability to handle uncertainty and failure, opportunity identification skills and self-confidence as prime factors in Tanzania.

In the context of South Africa, studies have shown variation in the nature of endogenous attributes required to run a successful small enterprises. A study by Bozas (2011) performed in uMhlathuze, KwaZulu-Natal Province identifies strict financial management, client management, sound planning and self-discipline as success-driving 
entrepreneurs' endogenous factors. Mmbengwa (2013) also mentioned these on the subject of innovation and risk-taking in the peri-urban poor communities of George Municipality in the Western Cape province. Nkondo (2017) and Iwara (2018) whose studies were performed in Thulamela Local Municipality in the Limpopo province, documented collaborative spirit, marketing and managerial skills as key endogenous attributes; however, which of these factors are peculiar to entrepreneurs in rural areas of Vhembe have still not been documented, and this may constrain targeted support for the area.

\section{Methodology}

This study was conducted in Vhembe District Municipality, Limpopo Province. Participants, SMMEs entrepreneurs, were drawn from villages within the four local municipalities in the District, namely, Collins Chabane, Makhado, Musina and Thulamela. This was performed using snowball and purposive sampling techniques and whilst the snowball sampling technique enabled one participant to refer to another, the purposive sampling technique was ideal in selecting entrepreneurs with not less than 5 year experience of business operation.

An exploratory mixed-method research design was adopted which allowed a quantitative research method to build on a qualitative one (Creswell \& Sinley 2017). The qualitative phase enabled the study to unearth endogenous factors responsible for successful enterprise development and the quantitative component of the study allowed for the clarification of the factors. The use of the Atlas-ti v8 open coding system for qualitative analysis extracted 49 attributes from a pool of participants' narratives (Figure 1). A 5-point Likert-type scale was then developed for scoring and measuring the attributes which was later tested on 280 participants.

Principal Component Analysis (PCA) fitted on the data dimension reduced the 49 variables to five principal components (Table 1). The Bartlett's test of sphericity and Kaiser-Meyer-Olkin measure (KMO) were used to test both sampling adequacy and the appropriateness of the variables (Table 2). In order to isolate successful enterprises from others, profit margin, trends of new products, enterprise survival and enterprise expansion factors were used as a standard for measuring performance. The Scale-Reliability Analysis was performed for Cronbach's Alpha test for quality assurance and reliability of the results. Furthermore, multicollinearity was tested using the Variant Inflation Factor (VIF) method. The importance of the five principal components identified from running PCA on 49 proxy attributes for examining enterprise development was investigated using two Linear Regression Models. Firstly, a regression model fitted on the overall sample $(n=280)$ (Table 3) and a regression model fitted on the sample that met success standards of the study $(n=83)$ (Table 4$)$.

\section{Ethical considerations}

The ethical approval was obtained from the University of Venda Research Ethical Committee, SARDF/19/ IRD/01/2603.

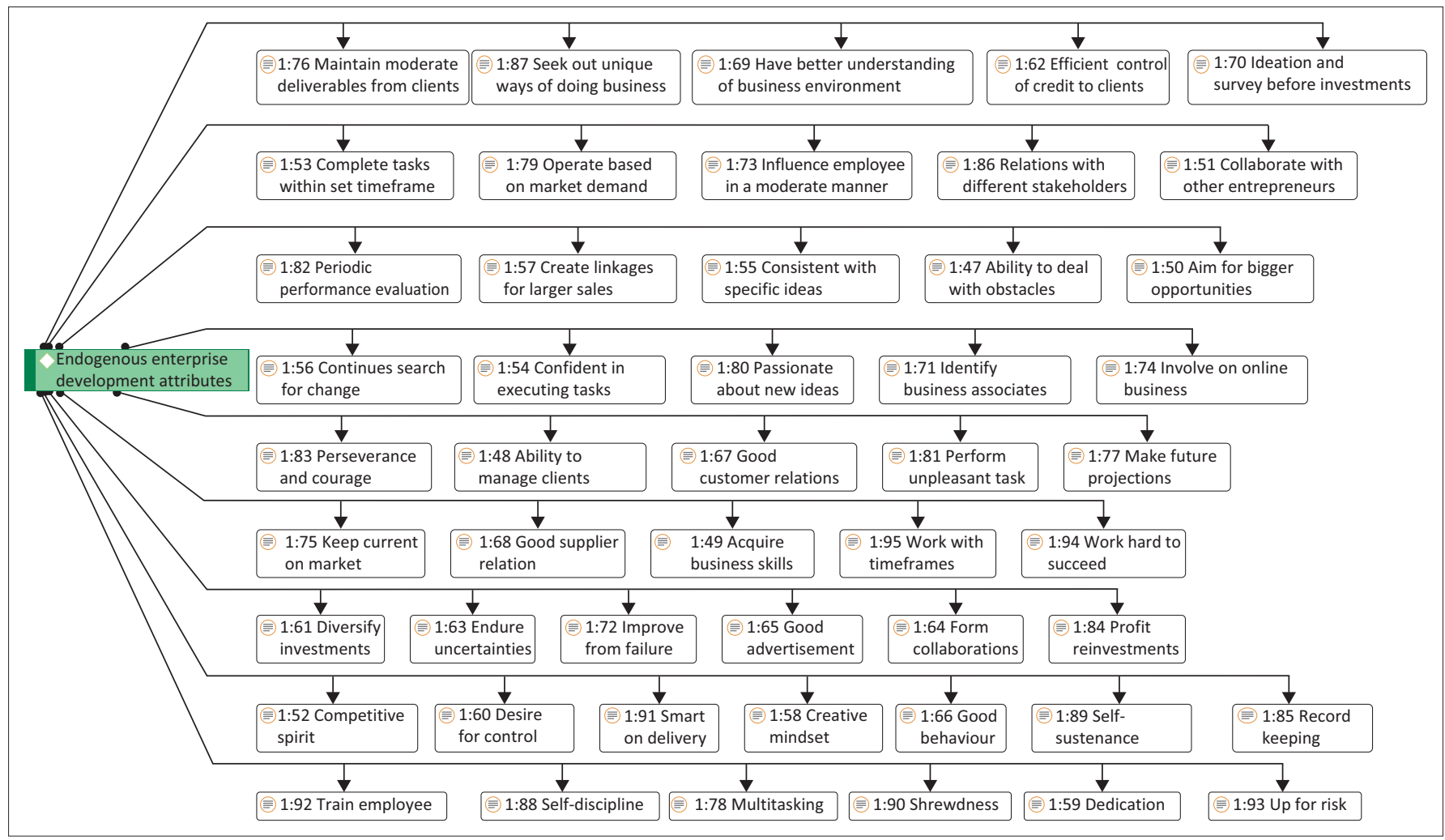

FIGURE 1: Network diagram showing endogenous variables influencing SME success. 
TABLE 1: Endogenous factor loading and communalities based on a principal component analysis with varimax rotation ( $n=280)$.

\begin{tabular}{|c|c|c|c|c|c|c|}
\hline Factor loading & $\begin{array}{c}\text { Factor 1: Bridging } \\
\text { networks }\end{array}$ & Factor 2: Self-belief & $\begin{array}{c}\text { Factor 3: Risk } \\
\text { awareness }\end{array}$ & Factor 4: Resilience & $\begin{array}{l}\text { Factor 5: Non- } \\
\text { conformist }\end{array}$ & Communalities \\
\hline Create linkages for larger sales & 0.910 & - & - & - & - & 0.948 \\
\hline Continuous search for change & 0.877 & - & - & - & - & 0.876 \\
\hline Diversify investments & 0.875 & - & - & - & - & 0.870 \\
\hline Involvement in online business & 0.850 & - & - & - & - & 0.888 \\
\hline Consistent with specific business ideas & 0.841 & - & - & - & - & 0.879 \\
\hline Form collaboration and partnership & 0.802 & - & - & - & - & 0.670 \\
\hline Aim for bigger opportunities & - & 0.870 & - & - & - & 0.801 \\
\hline Complete task within set timeframe & - & 0.852 & - & - & - & 0.755 \\
\hline Effective control of credit to client & - & 0.817 & - & - & - & 0.719 \\
\hline Good supplier relations & - & 0.795 & - & - & - & 0.753 \\
\hline Make future projections & - & 0.778 & - & - & - & 0.668 \\
\hline Good customer relations & - & 0.711 & - & - & - & 0.538 \\
\hline Desire for control & - & - & 0.798 & - & - & 0.868 \\
\hline Maintain moderate receivables from clients & - & - & 0.789 & - & - & 0.830 \\
\hline Ideation and survey before investments & - & - & 0.748 & - & - & 0.942 \\
\hline Profit reinvestments & - & - & 0.668 & - & - & 0.638 \\
\hline Influence employee in a moderate manner & - & - & 0.659 & - & - & 0.800 \\
\hline Work with timeframe & - & - & 0.639 & - & - & 0.706 \\
\hline Confidence in executing task & - & - & - & 0.696 & - & 0.632 \\
\hline Ability to deal with obstacles & - & - & - & 0.659 & - & 0.662 \\
\hline Perseverance and courage & - & - & - & 0.501 & - & 0.631 \\
\hline Improve from failure & - & - & - & 0.497 & - & 0.701 \\
\hline Perform unpleasant tasks & - & - & - & - & 0.738 & 0.858 \\
\hline Variance $(\%)$ & 38.044 & 15.802 & 6.144 & 4.532 & 4.271 & 68.794 \\
\hline Test of reliability: Cronbach's alpha & 0.956 & 0.927 & 0.927 & 0.458 & 0.811 & - \\
\hline Number of items extracted & 7 & 7 & 6 & 4 & 2 & 26 \\
\hline
\end{tabular}

TABLE 2: Kaiser-Meyer-Olkin and Bartlett's test.

\begin{tabular}{lll}
\hline Test & Variable & Value \\
\hline $\begin{array}{l}\text { Kaiser-Meyer-Olkin measure of } \\
\text { sampling adequacy }\end{array}$ & - & 0.914 \\
Bartlett's test of sphericity & Approx. Chi-square & 17470.862 \\
& $d f$ & 1176 \\
& Sig. & 0.000 \\
\hline
\end{tabular}

$d f$, degrees of freedom; Sig., significance; Approx, approximately.

TABLE 3: The significant endogenous variables influencing small and micro scale enterprises success $(n=280)$.

\begin{tabular}{lccccccc}
\hline Parameters & Estimate & $\begin{array}{c}\text { Std. } \\
\text { error }\end{array}$ & $t$ & $\operatorname{Pr}(>|t|)$ & \multicolumn{2}{c}{$\begin{array}{c}\text { Collinearity } \\
\text { statistics }\end{array}$} \\
\cline { 3 - 7 } & & & & & Tolerance & VIF \\
\hline (Intercept) & 32.7857 & 0.758 & 43.234 & $0.000^{*}$ & - & - \\
Bridging networks (BN) & 21.6810 & 0.760 & 28.533 & $0.000 *$ & 1.000 & 1.000 \\
Self-belief (SB) & 1.3521 & 0.760 & 1.787 & 0.075 & 1.000 & 1.000 \\
Risk awareness (RA) & 6.185 & 0.760 & 8.141 & $0.000^{*}$ & 1.000 & 1.000 \\
Resilience (R) & 2.984 & 0.760 & 3.928 & $0.045^{*}$ & 1.000 & 1.000 \\
Non-conformist (NC) & 1.462 & 0.760 & 1.925 & 0.055 & 1.000 & 1.000 \\
\hline
\end{tabular}

Note: $R$-Squared $=0.767$; Overall VIF value $=4.291$

The model intercept is statistically significant $(t=43.23, p<0.05)$. The VIF value is below 5.0 indicating that the assumption of the absence of multicollinearity was met.

$\mathrm{VIF}=\frac{1}{1-R^{2}}$

$\mathrm{VIF}$, variant inflation factor; Std. error, standard error; Pr, prevalence of ratio.

$*, p<0.05$.
TABLE 4: The significant endogenous variables influencing SME success $(n=83)$. \begin{tabular}{lllll}
\hline Parameters & Estimate & Std. & $t$ & $\operatorname{Pr}(>|t|)$ Collinearity statistics
\end{tabular}

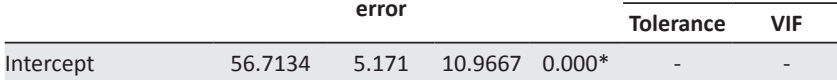

$\begin{array}{lllllll}\text { Bridging networks } & 7.5751 & 3.049 & 2.484 & 0.015^{*} & 0.691 & 1.448\end{array}$

(BN)

$\begin{array}{lllllll}\text { Self-belief (SB) } & -1.053 & 1.358 & -0.7776 & 0.439 & 0.493 & 2.027\end{array}$

$\begin{array}{lllllll}\text { Risk awareness (RA) } & 1.324 & 2.634 & 0.503 & 0.617 & 0.467 & 2.140\end{array}$

$\begin{array}{llllllll}\text { Resilience (R) } & 3.700 & 2.275 & 1.626 & 0.108 & 0.547 & 1.827\end{array}$

\begin{tabular}{lllllll} 
Non-conformist (NC) & 0.948 & 2.029 & 0.467 & 0.642 & 0.552 & 1.811 \\
\hline
\end{tabular}

Note: $R$-Squared $=0.163$; Overall VIF value $=1.1947$. The model intercept is statistically significant $(t=10.97, p<0.05)$. The VIF value is below 2.0 , indicating that the assumption of

the absence of multicollinearity was met. VIF $=\frac{1}{1-R^{2}}$

VIF, variant inflation factor; Std. error, standard error; Pr, prevalence of ratio. $*, p<0.05$.

\section{Results}

Results obtained from Atlas-ti qualitative analysis present 49 endogenous attributes inherent in entrepreneurs (Figure 1). The use of PCA in the quantitative analysis reduced the data structure made up of 280 rows and 49 variables to five principal components (see Figure 2). The first five variables selected have eigen values over two; together, they explain over $68.796 \%$ of the total variability in the data structure, thus, the remaining 44 variables account for $31.204 \%$ (Table 1 ). 


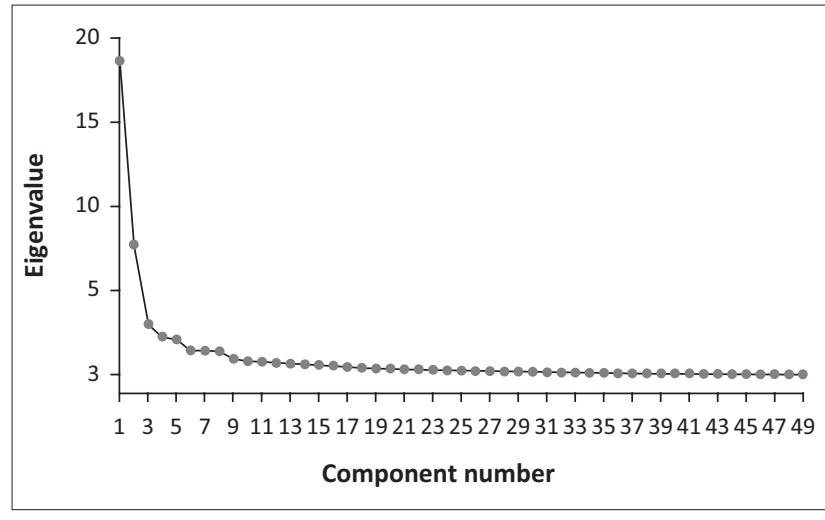

FIGURE 2: The scree plot and eigen-values used to extract endogenous factors.

This leads us to the conclusion that a five-factor solution is adequate.

The first factor explained $38.044 \%$ variance which is the highest. It was labelled 'bridging networks $(\mathrm{BN})$ ' because of high loadings by the following items - create linkages for larger sales (0.910), continuous search for change (0.877), diversify investments (0.875), involvement in online business (0.850), consistent with specific business ideas (0.841) and identify with business associations (0.840), collaboration and partnership (0.802). The second factor was labelled 'SB' because of high loading by the following variables - aim for bigger opportunities (0.870), complete task within set timeframe (0.852), effective control of credit to client (0.817), good relationship with suppliers (0.795), make future projections (0.778), self-sustenance (0.766) and good customer relations $(0.711)$. The variance explained by this factor was $15.802 \%$.

The third factor from the PCA was labelled 'risk awareness (RA)' because of high loadings of the following items - desire for control (0.798), maintain moderate receivables from clients (0.789), ideation and survey before investments $(0.748)$, profit reinvestments (0.668), influence employee in a moderate manner (0.659) and work with timeframe (0.639). The variance that loaded in the factor was $6.144 \%$. The fourth factor was named 'resilience $(\mathrm{R})$ ' given that it loaded - confidence in executing a task (0.696), ability to deal with obstacles (0.659), perseverance and courage (0.501) and improve from failure (0.497). The factor had $4.532 \%$ variance. The fifth factor was called 'nonconformist' because of high loadings by the following items - perform unpleasant tasks (0.738) and seek out unique ways of doing business (0.587). The variance explained by this factor was $4.271 \%$, which is the least amongst the five factors extracted in the PCA. Except for one item (improve from failure) which had a variance of $0.497 \%$, other 25 out of the 26 extracted items in the PCA loaded 50 and above. This reflects that the factors extracted a large variance.

The Cronbach's Alpha reliability test performed for quality assurance yielded the following points for the five factors: 0.956, 0.927, 0.927, 0.458 and 0.811. The KMO was 0.914 (Table 2), supporting Halim et al. (2014) who maintained that the $\mathrm{KMO}$ is most acceptable at 0.50 and above. Bartlett's test of sphericity yielded 17470.862 with 0.00 significance, showing the level of appropriateness to utilise PCA. The result showing loading and commonalities based on a PCA with a varimax rotation $(n=280)$ is presented (Table 1$)$.

\section{Regression model endogenous variables}

The model relating enterprise success with five endogenous factors identified from running PCA on the survey data (Table 3 ) is given as (Equation 1):

$$
\hat{P}_{i}=32.78+21.68 \widehat{B N}_{i}+1.35 \widehat{S B}_{i}+6.18 \widehat{R A}_{i}+2.98 \hat{R}_{i}+1.46 \widehat{N C}_{i}
$$

Where $\mathrm{P}$ (Performance) is the dependent variable and $\mathrm{BN}, \mathrm{SB}$, $\mathrm{RA}, \mathrm{R}$ and NC (Non-Conformist) are the explanatory variables of the regression model. The test for multicollinearity performed using the VIF method yielded 4.291. This is below five and within the scientific acceptable limit, thus, there is no significant presence of multicollinearity that may cause turbulence. The model, therefore, is adequate and the result is reliable.

The intercept value of $\beta_{0}=32.78$ is the value of enterprise performance when all explanatory variables are held constant, that is, $\mathrm{BN}=\mathrm{SB}=\mathrm{RA}=\mathrm{R}=\mathrm{NC}=0$. The intercept value is statistically significant at $5 \%$ level of significance $(t=43.2, p<0.05)$. This means that the value of the intercept is significantly different from zero as was assumed by the null hypothesis $\left(H_{0}: \beta_{0}=0\right)$ which, in this case, was rejected in favour of the alternative hypothesis $\left(H_{0}: \beta_{0} \neq 0\right)$.

The coefficient value for the $\mathrm{BN}$ variable is $\beta_{1}=21.6$, implying that enterprise performance increases by $21.6 \%$ for every unit increase in the rating of the variable, when all other explanatory variables are held constant (that is, $\mathrm{SB}=\mathrm{RA}=\mathrm{R}=\mathrm{NC}=0$ ). In the context of this study, this means that as the rating for the $\mathrm{BNs}$ variable increases, the performance rating also increases. The coefficient value of the BNs variable is statistically significant at $5 \%$ level of significance $(t=28.5, p<0.05)$ implying that the parameter value is different from zero.

The coefficient value of the SB variable $\left(\beta_{2}=1.35\right)$ tells us that the performance increases by $1.35 \%$ for every unit increase in the rating of the variable when all other independent variables are set to zero (that is, $\mathrm{BN}=\mathrm{RA}=\mathrm{R}=$ $\mathrm{NC}=0$ ). This parameter is non-statistically significant at $5 \%$ level of significance $(t=1.78, p=0.07)$ implying that the parameter value was different from zero. The RA coefficient value of $\beta_{3}=6.18$ as reported, signifies $6.18 \%$ increase in enterprise performance for every unit increase in the rating of the variable whilst holding other variables constant $(\mathrm{BN}=\mathrm{SB}=\mathrm{R}=\mathrm{NC}=0)$. The parameter value is statistically significant at $5 \%$ level of significance $(t=8.14, p<0.05)$, thus, the coefficient value for the RA is different from zero.

Regarding the $\mathrm{R}$ variable, a parameter value of $\beta_{4}=2.98$ was reported implying that every unit increase in the factor 
causes enterprise performance to increase by $2.98 \%$ whilst holding other independent variables constant. This parameter value is statistically significant at $5 \%$ level of significance ( $t=3.92, p<0.05)$, therefore, the null hypothesis that the coefficient value was equal to zero is rejected in favour of the alternative hypothesis which says that the coefficient value was different from zero. The coefficient value for the NC variable of $\beta_{5}=1.92$ was reported implying that enterprise performance increases by $1.92 \%$ for every unit increase in the rating of the variable. The parameter value is statistically insignificant at $5 \%$ level of significance $(t=3.95, p<0.055)$, implying that the coefficient value for the $\mathrm{NC}$ is indifferent from zero.

Overall, the model is statistically significant at $5 \%$ level of significance $(\mathrm{F}[5.274]=180.6, p<0.05)$, thus, having the ability to explain $77 \%$ of the total variation in enterprise performance (adjusted $R$-squared value $=0.76$ ). Also, based on the above results, it can be inferred that $\mathrm{BN}$ and $\mathrm{RA}$ are the most important factors amongst all five factors influencing enterprise performance towards success, followed by others.

\section{Regression model, endogenous variables $(n=83)$}

The Multi Linear Regression (MLR) was fitted to investigate enterprise success and five principal components based on the data structure of successful enterprises $(n=83)$ and the results are explicitly stated (Table 4 ). The model is given as (Equation 2):

$$
\hat{P}_{i}=56.71+7.57 \widehat{B N}_{i}-1.05 \widehat{S B}_{i}+1.32 \widehat{R A}_{i}+3.70 \hat{R}_{i}+0.94 \widehat{N C}_{i}
$$

The multicollinearity test using VIF indicates that the overall VIF value for the data structure fitted in the model is 1.1947, which is less than two. This implies the absence of multicollinearity in the dataset, thus, the model is adequate and the result is reliable.

The intercept value of $\beta_{0}=56.71$ means that the value of performance is constant at $56.71 \%$ when all other variables are held constant (that is, when $\mathrm{BN}=\mathrm{SB}=\mathrm{RA}=\mathrm{R}=\mathrm{NC}=0$ ). The intercept value is statistically significant at $5 \%$ level of significance $(t=10.97, p<0.05)$ implying that the intercept value is different from zero (that is, the null hypothesis that $\beta_{0}=0$ is rejected in favour of the alternative hypothesis $\left(H_{0}: \beta_{0} \neq 0\right)$. The coefficient value of $\left(\beta_{1}=7.58\right)$ for the $\mathrm{BN}$ variable shows a $7.58 \%$ increase in performance per every unit increase in the rating of the variable when other explanatory variables are held constant (that is, $\mathrm{SB}=\mathrm{RA}=\mathrm{R}=\mathrm{NC}=0$ ). This parameter value is statistically significant at $5 \%$ level of significance $(t=2.48, t=p=0.01)$, that is, the parameter value of $\beta_{1}=7.58$ is different from zero as the null hypothesis that $\beta_{1}=0$ is rejected in favour of the alternative hypothesis $\left(H_{\mathrm{a}}: \beta_{1} \neq 0\right)$.

The coefficient value $\left(\beta_{2}=-1.05\right)$ for the SB variable means that performance decreases by $1.05 \%$ for every unit increase in the variable when other explanatory variables are held constant, (that is, $\mathrm{BN}=\mathrm{RA}=\mathrm{R}=\mathrm{NC}=0$ ); however, the parameter value $(t=-0.78, p=0.43)$ is not statistically significant at $5 \%$ level of significance, implying that the parameter value of the variable is indifferent from zero as it failed to reject the null hypothesis that $\beta_{2}=0$. Similarly, the coefficient value for the RA variable of $\beta_{3}=1.32$ means that enterprise performance will increase by $1.30 \%$ for every unit improvement on the factor whilst other independent variables are held constant $(\mathrm{BN}=\mathrm{SB}=\mathrm{R}=\mathrm{NC}=0)$; however, this parameter value is statistically non-significant as the null hypothesis is retained at $5 \%$ level of significance $(t=0.50, p=0.61)$.

A coefficient value of $\beta_{4}=3.70$ is reported for the $\mathrm{R}$ factor. The parameter value means that for every unit increase in the rating of the $\mathrm{R}$ variable, enterprise performance will increase by $3.70 \%$. This parameter is statistically non-significant at $5 \%$ level of significance $(t=1.62, p=0.10)$ implying that it cannot be differentiated from zero (the null hypothesis of $\beta_{4}=0$ is retained). A coefficient value of $\beta_{5}=0.94$ was reported for the NC variable. This implies that enterprise performance will increase by $0.94 \%$ for every unit increase in the rating of the factor when other explanatory variables $(\mathrm{BN}=\mathrm{SB}=\mathrm{RA}=\mathrm{R})$ are set to 0 . This parameter is statistically insignificant at $(t=0.50, p=0.64)$, thus, at this level of significance, $\hat{\beta}_{5}$ cannot be differentiated from zero.

Overall, the model is statistically significant at 5\% level of significance $\left(F_{5.77}=2.998, p=0.00\right)$. Also, it can be inferred that using the coefficients, $\mathrm{BN}$ still holds its position as the most important enterprise success factor followed by R, RA and $\mathrm{N}$ whilst SB is the least influential. Although, SB has the least impact amongst the five factors, it still needs to be carefully managed as it is negatively related to enterprise success. The model served its purpose for this study, given that it enabled inference to be made on the crucial nature of endogenous factors known to influence enterprise success in Vhembe, as obtained post-PCA.

\section{Discussion of findings}

Following a sequential exploratory mixed-method research design, five components emerged as important endogenous predisposing enterprise success. In descending order of importance, they are - BNs, non-conforming, RA, $\mathrm{R}$ and SB. The discussion of the finding follows this hierarchy of the result.

\section{Bridging networks}

Based on the result, 'BNs' as a component encompasses attributes such as creating linkages for larger sales, continuous search for change, involvement in online business, business collaboration and partnerships as well as connecting with other relevant business associations. In the context of this study, $\mathrm{BN}$ is the ability to connect and interrelate through various channels that are paramount to business growth. It explains the capacity to establish good relationships with various individuals within and beyond family boundaries (Souza et al. 2016). Entrepreneurs BNs 
connect them with people who may directly or indirectly support their ideas (Akhtar et al. 2015). Through this component, entrepreneurs are able to operate with others in a concerted effort to achieve a goal (Duchaine et al. 2007), and this is essential for expanding the scale of operation. Networking begins with entrepreneurs' mindset, believing that their ideas are resourceful to society and that people around them have a significant role to play in it. From the narrative, it was explained that:

'Well, the local demand is very little to reach the desired target. We go to urban areas, search for larger firms to supply our products in wholesales. Although the profit is lesser when compared with retails it is preferable given the constant flow of supplies in larger amount ...' (Participant 19, 31 years old)

'Reaching out to big companies or organisation helps a lot. Initially, carrot and beetroot were the only products I supplied. At some point, one of the hotels I had spoken to indicated that there was demand for potatoes in large quantity. At the initial stage, I would buy from others to supply, however, I have started my production on a large scale ...' (Participant 41, 27 years old)

Networking in business has been widely discussed as an important component not only to enterprise performances but also its formation and sustainability. According to Mlotshwa and Msimango-Galawe (2020), the more entrepreneurs were involved in networking that relates to their business ideas and maintain the relationships effectively, and their businesses would perform better. In Asia, for instance, the Bazaar entrepreneurship model, Kaizen entrepreneurship model and Wenzhou model of entrepreneurship have networking as an important component (Dana 2014; Fukase 2015; Graupp \& Wrona 2015; Wang, Chen \& Zang 2005). These models were built on the assumption that they will enable connections with essential external stakeholders to promote collectivism community of practice in business which is very efficient in operating an enterprise. One of the participants mentioned:

'Taking a loan to start a good business in this country is a big deal ... aside the strenuous conditions for accessing such of which most people cannot afford, the interest rate is alarming, sometimes up to $30 \%$. One would end up doing the business for their creditors ... So, I canvassed and bring my friends into the business and then we agreed on certain amount each should contribute to start the business. Aside a few stakeholders we have met for marketing, we are doing perfectly well because all hands are on the desk.' (Participant 28, 34 years old)

Collectivism, a product of networking in business, enables people with a similar mindset to join resources to create a successful enterprise. Studies have shown that networking capacity is a potent factor behind the success of most foreignowned small enterprises in South Africa (Charman, Petersen \& Piper 2012; Nkondo 2017); this gives them a strong competitive advantage over the locals (Malgas \& Zondi 2020). These researchers explained that foreign entrepreneurs in South Africa, especially the Asians, often network through various platforms, connect with one another and collaborate amongst themselves in business. Networking, therefore, is an ideal skill for locally owned enterprises in the country and the government should invest in it.

\section{Resilience}

Research has shown that there is a positive relationship between resilient and business development (Kunaka \& Moos 2019). Resilience is the ability to endure hardships and uncertainties, and afterwards, recover from any shortfalls (Alon \& Shneor 2017). It explains the ability of entrepreneurs to adapt to disruptions that pose threats to businesses' existence (Kativhu 2019). A resilient entrepreneur, therefore, is steadfast in the pursuit of goals, and persistent in achieving success even in the presence of obstacles (Souza et al. 2016). From the narrative, a participant explains:

'Determination and perseverance are key ... people feel business will yield result from the moment they start, as a result quit after a while. This is not always the case. One must be passionate to follow their dreams regardless of obstacles and the growth level. I have a strong sense of belonging to my business. I learn from obstacles and each failure.' (Participant 11, 42 years old, male, non-supported in extremely rural area)

Resilience is pivotal to any enterprise or different forms of business ownership. This is because some ventures ended up failing for issues that could have been managed should there have been moderate R. A participant mentioned:

'This is my fifth year in this business ... I have failed three times in different years but I don't give up. Chicken is vulnerable to weather and certain living conditions as well as prey, so one is bound to encounter uncertainties. Sometimes, over $70 \%$ of them will die in my farm, and it is a lot of money ... I can only check what went wrong, sometimes change their feeds and medication, but I don't quit. When things are not okay, I operate in small scale until I regain ...' (Participant 7, 52 years old)

Participants' view of R and business sustainability corroborate those of Alon and Shneor (2017) who asserted that real entrepreneurs endure uncertainties and see how they could transform them into opportunities, whilst others give up. Lack of $\mathrm{R}$ would continue to impact negatively on entrepreneurs who have low potential to survive and succeed.

\section{Risk awareness}

Being aware of a possible risk is essential in directing the nature of investments and the day-to-day tasks of an enterprise (Pahuja \& Sanjeev 2015). This helps entrepreneurs to take precautions ahead of an obstacle and directs proper use of resources to maximise output (Saleem \& Abideen 2011). Despite its importance, most entrepreneurs are not risk-conscious; as a result they invest without taking precautions and fail in the long run. A supported female in a rural area mentioned:

'I am only operating a car wash business ... people are beginning to see the potentials in this business in the area and many are investing without minding its implications competition sets in as a result of homogeneity. To make a difference from what others are doing, I am looking for innovative way to render my service, and also look for alternative business to complement ...' (Participant 13, 38 years old)

In an effort to overcome the risk of failure, some enterprises diversify investments and/or shift resources to areas of 
higher yield, possibly with low cost as is also recommended by Amiri and Marimaei (2012) and Chavez (2016). Risk awareness helps one to have a sense of success and failure in their entrepreneurial endeavours (Oser \& Volery 2012). Such senses enable entrepreneurs to make proper adjustments that can assist them to avoid failure. It gives the ability to 'connect the dots' and the conviction to follow and efficiently execute an idea and succeed in business (Beattie 2016; Jan, Irshad \& Nadeem 2013), thus, it is important for entrepreneurs to be conscious of risk. For instance, an entrepreneur mentioned:

\begin{abstract}
'All businesses have strength, weakness, opportunities and threats. What makes a successful business is the understanding of these factors and how they can either be explored or managed appropriately to avoid failure. I constantly use these factors to evaluate any business action I am about to take; if returns to scale offer more than what I can give in, then the risk is worth taking, otherwise, walk away. Besides, I don't put in too much money at a go in one business initiative but invest in phases, bit by bit until it grows so that I don't lose much should the business fail.' (Participant 33, 57 years old)
\end{abstract}

Literature reveals that successful entrepreneurs take calculated and moderate risks (Chavez 2016; Karabulut 2016; Souza et al. 2016). The pertinent question, however, is - How does an entrepreneur understand what is worth doing? This notion is discussed from different perspectives. In the study area, successful entrepreneurs with ideation subject any business ideas to quality control and assurance before the business is rolled out. This is a sure method to measure the viability of an innovation. These findings are in line with Wang et al. (2005) and Alon and Shneor (2017) who emphasised the need to measure business fit by means of survey. In this, an idea is developed based on an existing gap, and is then tested for quality control before execution (Alon \& Shneor 2017; Darnihamedani 2016). An entrepreneur mentioned:

\begin{abstract}
'No matter how good a business idea, it will fail if not properly positioned. Before I even started, I did a bit of survey in the area to see what other enterprises are offering, what the society wants, and the area that could attract more customers ... Cost of production and external risk such as theft were prime factors in my survey. It is important to understand the nature of market one enters ...' (Participant 46, 31 years old)
\end{abstract}

Research showed that a moderate risk can be maintained by means of market survey (Chavez 2016) or trend analysis using business records (Jan et al. 2013). The approach supports Souza et al. (2016) who recommended periodic business evaluation and self-analysis to access performance. This provides a basic understanding of businesses with low impact for improvements or potential areas to shift investment direction. According to Haq (2015), an understanding of market environment, especially, needs of the society provide the basics for entrepreneurs to navigate smoothly. These attempts enable entrepreneurs to gain insight into the entrepreneurial ecosystem, and plan their enterprise appropriately in a manner that conforms to existing market needs (Auerswald 2015).
The current study also indicated that entrepreneurs reinvest profit in their enterprises to minimise risk of falling below competition. Some entrepreneurs work with timeframe, maintain moderate receivables from clients and influence employees in a moderate manner to deliver. This is consistent with the recommendation from Alon and Shneor (2017) that employees are variable factors of production, as such, they should be moderately influenced for efficient output. It is suspected that extreme influence and/or pressure on employees may result in stress and unproductivity. Some resourceful employees may quit in the event where they cannot withstand the excess pressure.

\section{Non-conforming}

Being a non-conformist is a sign of novelty, and such entrepreneurs are opportunity-driven and pace-setters. They tend to search for unique and innovative ways of addressing issues rather than the common ways used by their counterparts. An entrepreneur in the study area stated:

'I do my things my own way to make a difference, father better than what every other person does ... In this market environment, competition is high, people are always on the run to imitate anything one introduces, so one has to make a difference to remain relevant ... I do printing business, sell stationaries and other items here, some people have started the same thing around. What I did was that I negotiate with people around for delivery service. They could send their work to me through email or WhatsApp to print and bring to them. It makes it easier and convenient ...' (Participant 30, 26 years old)

The freedom to think differently from others makes some entrepreneurs exceptional, given equal opportunities (Beattie 2016; Parker 2018; Tidd \& Bessant 2018). According to Amiri and Marimaei (2012) and Amorós, Etchebarne and Felzensztein (2012), entrepreneurs who do not conform to prevailing idea often set a pace for others to follow. They have the ability to remodel existing ideas into new knowledge to solve unique problems (ed. Schumpeter 1934). An entrepreneur mentioned:

'Operate business on the basis of market principles and high needs, not following what others are doing ... Relevant experience and unique pattern of doing things is essential when venturing into a business, especially in farming, which is usually a common business many people can do even without a high level of specialized skills ... I just think aloud to make a little difference in everything I do, and this is the secret behind my success ...' (Participant 41, 53 years old)

Participants' views about venturing into successful businesses imply that for an enterprise to perform exceptionally well, given the high levels of competition, novelty is necessary as it enables them to explore better options, and operate innovatively from others. This reasoning conforms with Amorós et al. (2012) and Alon and Shneor (2017) who contended that having unique ways of doing business shows novelty and this is essential in aging enterprises. Non-conformists are inclined to risk investing proactively in areas that facilitate new product and wealth creation, rather than following prevailing ideas (AmankwahAmoah, Boso \& Antwi-Agyei 2018; Beattie 2016): 
'Fresh vegetables, fruits and potatoes have high demand in our local market, and everyone is into the business ... just too many of us ... however, I decided to deviate from others. Usually, people use inorganic fertilizers to grow their farms because the soil here is not fertile to guarantee rich products ... but I decided to go organic by using cow dung, chicken faeces and sawdust to grow mine ... targeting people with health issues and the upper class families. Organic products are less expensive to produce but costlier than those produced with inorganic fertilizers ...' (Participant 26, 32 years old)

Non-conformism provides new dimension for occupying the market by means of new ideas and products (Jan et al. 2013; Mbizi et al. 2013; Pahuja \& Sanjeev 2015; Abd Rani \& Hashim 2017). On the other hand, following similar ideas will cause homogeneity wherein too many products pursue few demands. Many entrepreneurs may not withstand the competition, hence, fail in the long run.

\section{Self-belief}

Self-belief explains the confidence and ability to succeed in specific situations or accomplish a task in the face of obstacle. It explains the extent to which an entrepreneur is certain about sufficient capabilities to perform various entrepreneurial tasks successfully (Galawe 2017; Abd Rani \& Hashim 2017). Entrepreneurs with high belief generally go for demanding tasks with hopes of maximising gains. According to a non-supported female entrepreneur in rural area:

'... in business, one should dream big, make projections and work towards them ... It can only be you and your business, so give it all efforts. Be the boss, take charge and effective control, total responsibility and account for every action ... most importantly, there must be elements of confidence, independence and selfsustenance to plan a business and ascertain good trajectories ...' (Participant 39, 61 years old)

Successful entrepreneurs have a mindset of self-sustenance, confidence in completing tasks within set timeframes, determination for bigger opportunities and a strong sense of controlling relations. Seen as a vital business attribute, Beattie (2016) and Alon and Shneor (2017) considered SB as an ability to independently approach, manage and complete an innovative task. Essentially, a SB mindset produces a sense of leadership and capacity to ensure that work is performed, at the most efficient time, using appropriate resources and at the barest minimum cost (Hsu, Wiklund \& Cotton 2017; Karabulut 2016; Souza et al. 2016). This is paramount in developing and managing a successful business and being an effective entrepreneur.

\section{Conclusion and recommendation}

Currently, the support being offered to small enterprises, especially in rural areas of South Africa, is mostly centred on exogenous factors and excludes endogenous attributes which are equally pivotal. Investments based on endogenous attributes are insufficient because of the widely shared narrative that exogenous supports, such as finance and access to market, are the only influential factors leading to success of SMEs. For successful entrepreneurship, however, exogenous and endogenous factors should be combined in finding strategies to support the SMEs. Unearthing specific entrepreneurs' endogenous attributes that should complement the exogenous factors for successful enterprises in the context of Vhembe rural areas revealed that $\mathrm{BN}$ is a key to enterprise success. Entrepreneurs showing $\mathrm{R}$, having RA, being $\mathrm{NC}$ and having SB are some of the endogenous factors influencing SME success in the areas. Studies have already isolated various endogenous factors in different areas; however, some are area-specific and this brings uncertainties on the precise nature of the support that should be given to grassroots entrepreneurs. The literature has not documented specific entrepreneurs endogenous factor support required in rural areas of Vhembe, making the current findings essential for contextspecific intervention. Most studies conducted on small enterprise in the area make reference to exogenous performance indicators such as small business start-up capital, access to finance, government regulations, security measures and competition from foreign businesses. It is expected, therefore, that these findings will better inform stakeholders on how best to capacitate the grassroots entrepreneurs by harnessing endogenous capital that can complement exogenous factors to ensure small enterprises' success:

- Whilst investing in exogenous factors, it is essential for policymakers, agencies and entrepreneurship development practitioners to see the need to also improve the endogenous attributes identified in this study. The five factors should be included in toolkits used for entrepreneurial capacity-building in the study area.

- Entrepreneurs should scale up on their endogenous attributes to enable them manage the business landscape and thrive.

- Future studies should endeavour to compare and contrast the five factors highlighted in this study with those from other areas of South Africa and beyond, to see how the indicators hold ground.

\section{Acknowledgements Competing interests}

The authors declare that they have no financial or personal relationships that may have inappropriately influenced them in writing this article.

\section{Authors' contributions}

I.O.I. was the lead researcher. B.M.K., J.Z. and V.O.N. supervised the research initiative.

\section{Funding information}

This research received no specific grant from any funding agency in the public, commercial or not-for-profit sectors. 


\section{Data availability}

Data available can only be shared through the research host (University of Venda), upon resonable request.

\section{Disclaimer}

The views and opinions expressed in this article are those of the authors and do not necessarily reflect the official policy or position of any affiliated agency of the authors.

\section{References}

Abd Rani, S.H. \& Hashim, N., 2017, 'Factors that influence women entrepreneurial success in Malaysia: A conceptual framework', International Journal of Research 4(1), 16-23.

Acs, Z.J., Szerb, L. \& Autio, E., 2015, The global entrepreneurship and development index. In Global Entrepreneurship and Development Index 2014, pp. 39-64, Springer, Cham.

Abor, J. \& Quartey, P., 2010, 'Issues in SME development in Ghana and South Africa', International Research Journal of Finance and Economics 39(6), 215-228.

Abouzaid, S., 2018, IFC family business governance handbook, 4th edn., International Financial Corporation, Washington, DC.

Agbenyegah, A.T., 2013, 'Challenges facing rural entrepreneurship in selected areas in South Africa', PhD thesis, North-West University, Potchefstroom.

Agwa-Ejon, J. \& Mbohwa, C., 2015, 'Financial challenges faced by SMMES in Gauteng South Africa', in International association for management of technology (IAMOT) conference proceedings, 08-11 June, pp. 1-15.

Akhtar, C.S., Ismail, K., Hussain, J. \& Umair-ur-Rehman, M., 2015, 'Investigating the modera_ting effect of family on the relationship between entrepreneurial orientation and success of enterprise: Case of Pakistani manufacturing SMEs', International Journal of Entrepreneurship and Small Business 26(2), 233-247.

Al-Youm, A-M., 2015, 'Hazem Hassan: Family businesses in Egypt not growing', Egypt Independent, 19 May, viewed 17 July 2019, from https://egyptindependent.com/ hazem-hassan-family-businesses-egypt-not-growing/.

Alon, I. \& Shneor, R., 2017, 'More than makeup: How Atsoko overcame the challenges of entrepreneurship in Tanzania', Global Business and Organizational Excellence 36(6), 25-33. https://doi.org/10.1002/joe.21811

Amankwah-Amoah, J., Boso, N. \& Antwi-Agyei, I., 2018, 'The effects of business failure experience on successive entrepreneurial engagements: An evolutionary phase model', Group \& Organization Management 43(4), 648-682. https://doi. org/10.1177/1059601116643447

Amiri, N.S. \& Marimaei, M.R., 2012, 'Concept of entrepreneurship and entrepreneurs traits and characteristics', Scholarly Journal of Business Administration 2(7), 150.

Amorós, J.E., Etchebarne, S. \& Felzensztein, C., 2012, 'International entrepreneurship in Latin America: Development challenges', Esic Market Economic and Business Journal 43(3), 497-512. https://doi.org/10.7200/esicm.143.0433.3i

Asah, F., Fatoki, O.O. \& Rungani, E., 2015, 'The impact of motivations, personal values and management skills on the performance of SMEs in South Africa', African Journal of Economic and Management Studies 6(3), 308-322. https://doi. org/10.1108/AJEMS-01-2013-0009

Asongu, S.A. \& Odhiambo, N.M., 2019, 'Challenges of doing business in Africa: A systematic review', Journal of African Business 20(2), 259-268. https://doi.org/10. $1080 / 15228916.2019 .1582294$

Auerswald, P.E., 2015, Enabling entrepreneurial ecosystems: Insights from ecology to inform effective entrepreneurship policy, Research series on city, metro and regional entrepreneurship, October 2015, Ewing Marion Kauffman Foundation, Kansas City, MO.

Baluku, M.M., Matagi, L., Musanje, K., Kikooma, J.F. \& Otto, K., 2019, 'Entrepreneurial socialization and psychological capital: Cross-cultural and multigroup analyses of impact of mentoring, optimism, and self-efficacy on entrepreneurial intentions', Entrepreneurship Education and Pedagogy 2(1), 5-42.

Beattie, S., 2016, 'Which entrepreneurial traits are the most critical in determining success', Otago Management Graduate Review 14(1), 13-20.

Belz, A., 2015, 'Women drive success of Somali mall in Minneapolis', Startribune, 31 August, 2015, viewed n.d., from https://www.startribune.com/women-drivesuccess-of-somali-mall-in-minneapolis/323386601/

Bensassi, S. \& Jabbour, L., 2017, Return migration and entrepreneurial success: An empirical analysis for Egypt, Global Labor Organization discussion paper no. 98.

Blume, L.E. \& Sargent, T.J., 2015, 'Harrod 1939', The Economic Journal 125(583), 350-377. https://doi.org/10.1111/ecoj.12224

Bozas, L.A., 2011, 'Key success factors for small businesses trading within the city of uMhlathuze', Published Masters dissertation, University of KwaZulu-Natal, Republic of South Africa.

Buchanan, L., 2015, The U.S. now has 27 million entrepreneurs, viewed 25 November 2018, from https://www.inc.com/leigh-buchanan/us-entrepreneurship-reachesrecord-highs.html.

Cant, M.C. \& Wiid, J.A., 2013, 'Establishing the challenges affecting South African SMEs', International Business \& Economics Research Journal (IBER) 12(6), 707-716. https://doi.org/10.19030/iber.v12i6.7869
Charman, A., Petersen, L. \& Piper, L., 2012, 'From local survivalism to foreign entrepreneurship: The transformation of the spaza sector in Delft, Cape Town', Transformation: Critical Perspectives on Southern Africa 78(1), 47-73. https://doi. Transformation: Critical Perspec
org/10.1353/trn.2012.0035

Chavez, J., 2016, The personality characteristics of an entrepreneur and their effects on the performance of a new business venture, Helsinki Metropolia University of Applied Sciences, Helsinki, viewed n.d., from https://core.ac.uk/download/ Applied Sciences,
pdf/45600476.pdf.

Chimucheka, T. \& Rungani, E.C., 2011, 'The impact of inaccessibility to bank finance and lack of financial management knowledge to small, medium and micro enterprises in Buffalo City Municipality, South Africa', African Journal of Business Management 5(14), 5509-5517.

Chu, H.M., Benzing, C. \& McGee, C., 2007, 'Ghanaian and Kenyan entrepreneurs: A comparative analysis of their motivations, success characteristics, and problems', Journal of Development Entrepreneurship 12(3), 295-322. https://doi. org/10.1142/S1084946707000691

Chuang, C.H. \& Liao, H.U.I., 2010, 'Strategic human resource management in service context: Taking care of business by taking care of employees and customers', Personnel Psychology 63(1), 153-196.

Creswell, J.W. and Sinley, R.C., 2017, 'Developing a culturally-specific mixed methods approach to global research', KZfSS Kölner Zeitschrift für Soziologie und Sozialpsychologie 69(2), 87-105. https://doi.org/10.1007/s11577-017-0453-2

Dana, L.P., 2007, 'Asian models of entrepreneurship: From the Indian union and the Kingdom of Nepal to the Japanese archipelago: Context, policy \& practice', Small Business Economics 28(1), 105-107.

Darnihamedani, P., 2016, Individual characteristics, contextual factors and entrepreneurial behaviour, no. EPS-2016-360-S\&E, viewed n.d., from https:// repub.eur.nl/pub/93280.

De Faria Cosme, H., 2012, 'Perceived production planning and control problems at Cataler South Africa', PhD thesis, University of KwaZulu-Natal, Durban.

Department of Trade and Industry (DTI), 2007, Integrated Strategy on the Promotion of Entrepreneurship and Small Enterproses, viewed n.d., from https://www. datocms-assets.com/7245/1574922892-integrated-strategy-on-the-promotionof-entrepreneurship-small-enterprises.pdf.

Djankov, S., Qian, Y., Roland, G. \& Zhuravskaya, E., 2007, What makes a successful entrepreneur? Evidence from Brazil, viewed 08 February 2019, from https://eml. berkeley.edu/.pdf.

Douglas, J., Douglas, A., Muturi, D. \& Ochieng, J., 2017, 'An exploratory study of critical success factors for SMEs in Kenya', in Toulon-Verona conference excellence in services, pp. 223-234, University of Verona, Verona.

Duchaine, P., Bourdages, B., Lecours, L., Marchesseault, C., St-Germain, L. \& Morneau, G., 2007, Entrepreneurial spirit in college: Entrepreneurial profile, Activity 4, viewed 18 February 2019, from: http://entrepreneuriat.inforoutefpt.org/ documents/File/ANG_Profil.pdf.

Fukase, A., 2015, 'Mitsubishi UFJ joins crusade on cross-shareholding', Wall Street Journal, July 31, 2015, viewed n.d., from https://www.wsj.com/articles/ mitsubishi-ufj-joins-crusade-on-cross-shareholding-1438345700

Galawe, N.J., 2017, 'Endogenous and exogenous risk factors in the success of South African small medium enterprises', PhD thesis, University of the Witwatersrand, Johannesburg.

Graupp, P. \& Wrona, B., 2015, The TWI workbook: Essential skills for supervisors, Productivity Press, New York, NY

Ha, M., Siriwan, U., Ramabut, C., Thitikalaya, N., Thitikanlaya, T. \& Kiatnarong, C. 2014, 'Key factors for successful entrepreneurship in Thailand', Open Journal of Social Sciences 2(9), 116. https://doi.org/10.4236/jss.2014.29020

Halim, M.B.A. \& Ishak, M.A., 2014, 'Post-election behavior? Is it possible? A framework based on Hirschman (1970) model', Australian Journal of Basic and Applied Sciences 88(12), 67-75.

Hansen, A., Kimeria, C., Ndirangu, B., Oshry, N. \& Wendle, J., 2012, Assessing credit guarantee schemes for SME finance in Africa: Evidence from Ghana, Kenya, South Africa and Tanzania, AFD working paper 123.

Haq, M., 2015, 'South Asian ethnic minority small and medium enterprises in the UK: A review and research agenda', International Journal of Entrepreneurship and small business 25(4), 494-516. https://doi.org/10.1504/IJESB.2015.070222

Hsu, D.K., Wiklund, J. \& Cotton, R.D., 2017, 'Success, failure, and entrepreneurial reentry: An experimental assessment of the veracity of self-efficacy and prospect theory', Entrepreneurship Theory and Practice 41(1), 19-47. https://doi. org/10.1111/etap.12166

Iwara, I.O., 2018, 'Endogenous attributes of successful youth entrepreneurs in selected wards of Thulamela Local Municipality', Master's dissertation, University of Venda, Thohoyandou.

Iwara, I.O., Netshandama, V.O., Kilonzo, B. \& Zuwarimwe, J., 2019, 'Socio-cultural issues contributing to poor youth involvement in entrepreneurial activities in South Africa: A prospect of young graduates in Thohoyandou', African Journal of Development Studies 9(2), 111-134. https://doi.org/10.31920/2075-6534/2019/9n2a6

Jan, S., Irshad, M. \& Nadeem, A., 2013, 'Determinant of the success factors for entrepreneurship business', International Review of Basic and Applied Sciences 1(7), 156-164.

Karabulut, A.T., 2016, 'Personality traits on entrepreneurial intention', Procedia-Socia and Behavioral Sciences 229, 12-21. https://doi.org/10.1016/j.sbspro.2016.07.109

Kativhu, S., 2019, Criteria for measuring resilience of youth-owned small retail businesses in selected rural areas of Vhembe District, South Africa, viewed n.d., from https://www.semanticscholar.org/paper/Criteria-for-measuring-resilienceof-youth-owned-in-Kativhu/2522bf8798f5bcffof040c0abff8693e3ca1b23f. 
Kato, A.I. \& Tsoka, G.E., 2020, 'Impact of venture capital financing on small-and medium-sized enterprises' performance in Uganda', The Southern African Journa of Entrepreneurship and Small Business Management 12(1), 11. https://doi. of Entrepreneurship and Small
org/10.4102/sajesbm.v12i1.320

Krejcí, M., Strielkowski, W. \& Čabelková, I., 2015, 'Factors that influence the success of small and medium enterprises in ICT: A case study from the Czech Republic' Business: Theory and Practice/Verslas: Teorija ir Praktika 16(3), 304-315. https:// Business: Theory and Practice//2
doi.org/10.3846/btp.2015.521

Kunaka, C. \& Moos, M., 2019, 'Evaluating mentoring outcomes from the perspective of entrepreneurs and small business owners', The Southern African Journal of Entrepreneurship and Small Business Management 11(1), a214. https://doi. org/10.4102/sajesbm.v11i1.214

Ladzani, W., 2010, 'Historical perspective of small business development initiatives in South Africa with special reference to Limpopo province', Problems and Perspectives in Management 8(3), 68-79.

Ladzani, W. \& Netswera, G., 2009, 'Support for rural small businesses in Limpopo province, South Africa', Development Southern Africa 26(2), 225-239. https://doi. org/10.1080/03768350902899512

Lekhanya, L.M. \& Mason, R.B., 2014, 'Selected key external factors influencing the success of rural small and medium enterprises in South Africa', Journal of Enterprising Culture 22(3), 331-348. https://doi.org/10.1142/S0218495814500149

Limpopo Economic Development Enterprise (LEDE), 2006, Roots for growth and development, viewed 13 December 2018, from https://www.limdev.co.za/about.htm

Madichie, N.O., Mpiti, N. \& Rambe, P., 2019, 'Impact assessment of funding on technology acquisition by small businesses: A case study of hair salons in a South African municipality', Journal of Enterprising Communities: People and Places in the Global Economy 13(1/2), 145-166.

Madzimure, J., 2020, 'Examining the influence of supplier integration on supply chain performance in South African small and medium enterprises', The Southern African Journal of Entrepreneurship and Small Business Management 12(1), a312. https://doi.org/10.4102/sajesbm.v12i1.312

Maina, S.W., 2012, 'Factors influencing the development of youth entrepreneurship in Ongata Rongai Township, Kajiado County, Kenya', Unpublished PhD thesis, University of Nairobi, Nairobi.

Malebana, M.J., 2017, 'Knowledge of entrepreneurial support and entrepreneuria intention in the rural provinces of South Africa', Development Southern Africa 34(1), 74-89. https://doi.org/10.1080/0376835X.2016.1259990

Malgas, M. \& Zondi, W.B., 2020, 'Challenges facing small business retailers in selected South African townships', The Southern African Journal of Entrepreneurship and Small Business Management 12(1), a202. https://doi.org/10.4102/sajesbm.v12i1.202

Mbizi, R., Hove, L., Thondhlana, A. \& Kakava, N., 2013, 'Innovation in SMEs: A review of its role to organisational performance and SMEs operations sustainability', Interdisciplinary Journal of Contemporary Research in Business 4(11), 370-389.

Mlotshwa, S.H. \& Msimango-Galawe, J., 2020, 'The risk of overvaluing networking on small and medium enterprises performance in Gauteng province, South Africa', The Southern African Journal of Entrepreneurship and Small Business Management 12(1), a294. https://doi.org/10.4102/sajesbm.v12i1.294

Mmbengwa, V.M, Groenewald, J.A. \& Van Schalkwyk, H.D., 2013, 'Evaluation of the entrepreneurial success factors of small, micro and medium farming enterprises (SMMEs) in the peri-urban poor communities of George municipality, Western Cape Province, RSA', African Journal of Business Management 7(25), 2459-2474.

Mongia, A.K., 2013, Characteristics and attitudes of successful entrepreneurs: $A$ comparable study of Norwegian entrepreneurs in Norway and in the US, viewed n.d., from http://docplayer.net/24158428-Characteristics-and-attitudes-ofn.d., from http://docplayer.
successful-entrepreneurs.html.

Moos, M. \& Sambo, W., 2018, 'An exploratory study of challenges faced by small automotive businesses in townships: The case of Garankuwa, South Africa', Journal of Contemporary Management 15(1), 467-494.

Murugesan, R. \& Jayavelu, R., 2017, 'The influence of big five personality traits and self-efficacy on entrepreneurial intention: The role of gender', Journal of entrepreneurship and innovation in emerging economies 3(1), 41-61.

Musa, B.M. \& Semasinghe, D.M., 2013, 'Entrepreneurship and unemployment: A literature review', in International conference on business \& information, p. 2.

Nheta, D.S., Shambare, R., Sigauke, C. \& Tshipala, N., 2020, 'Entrepreneurship gaps framework model: An early-stage business diagnostic tool', The Southern African Journal of Entrepreneurship and Small Business Management 12(1), 7. https:// doi.org/10.4102/sajesbm.v12i1.297

Nkondo, L.G., 2017, 'Comparative analysis of the performance of Asian and Blackowned small supermarkets in rural areas of Thulamela Municipality, South Africa', PhD thesis, University of Venda, Thohoyandou.

Nyamunda, J. \& Van Der Westhuizen, T., 2018, 'Youth unemployment: The role of transformative learning in making the youth explore entrepreneurship', Journal of Contemporary Management 15(1), 314-343.
Oser, F. \& Volery, T., 2012, 'Sense of failure and sense of success among entrepreneurs: The identification and promotion of neglected twin entrepreneurial competencies', Empirical Research in Vocational Education and Training 4(1), 27-44. https://doi. org/10.1007/BF03546505

Pahuja, A. \& Sanjeev, R., 2015, Introduction to entrepreneurship, viewed 16 May 2019, from https://bit.ly/2BYJOKS

Parker, S.C., 2018, The economics of entrepreneurship, Cambridge University Press, New York, NY

Rabie, C., Cant, M.C. \& Wiid, J.A., 2016, 'Training and development in SMEs: South Africa's key to survival and success?', The Journal of Applied Business Research 32(4), 1009-1023. https://doi.org/10.19030/jabr.v32i4.9717

Ramukumbasup, V.M.T., Groenewald, J.A., Van Schalkwyk, H.D., Gundidza, M.B. \& Maiwashe, A.N., 2011, 'Factors that influence the success and failure of land bank supported farming small, micro and medium enterprises (SMMES) in South Africa', Journal of Development and Agricultural Economics 3(2), 35-47.

Republic of South Africa (RSA), 1998, White paper on local government: Ministry of provincial affairs and constitutional development, Government Printer, Pretoria.

Rose, R.C., Kumar, N. \& Yen, L.L., 2006, 'The dynamics of entrepreneurs' success factors in influencing venture growth', Journal of Asia Entrepreneurship and Sustainability 2(3), 1-19. https://doi.org/10.3844/jssp.2006.74.80

Saleem, S. \& Abideen, Z., 2011, 'Examining success factors: Entrepreneurial approaches in mountainous regions of Pakistan', European Journal of Business and Management 3(4), 56-67.

Schumpeter, J.A. (ed.), 1934, The theory of economic development: An inquiry into profits, capital, credits, interest, and the business cycle, transl. from the German by Redvers Opie, Transaction Publishers, New Brunswick.

Small Enterprise Development Agency (SEDA), 2014, Annual review 2013/2014: SEDA technology programme, Small Enterprise Development Agency, Pretoria.

Siriwan, U., Ramabut, C., Thitikalaya, N. \& Pongwiritthon, R., 2013, 'The management of small and medium enterprises to achieve competitive advantages in Northern Thailand', International Journal of Arts \& Sciences 6(1), 147.

Sledzik, K., 2013, Schumpeter's view on innovation and entrepreneurship in management trends in theory and practice, S. Hittmar (ed.), Faculty of Management Science and Informatics, University of Zilina \& Institute of Management, University of Zilina. pp. 89-95, viewed n.d., from https://www. academia.edu/5396861/SCHUMPETER_S_VIEW_ON_INNOVATION_AND_ ENTREPRENEURSHIP.

South Africa (SA) Economic Development Department, 2014, Small business promotion project, SMME Toolkit, version 4, Economic Development Department, promotion
Pretoria.

Souza, G.H.S.D., Santos, P.D.C.F.D., Lima, N.C., Cruz, N.J.T.D. \& Lezana, A.G.R., 2016, 'Entrepreneurial potential and success in business: A study on elements of convergence and explanation', RAM: Revista de Administração Mackenzie 17(5), 188-215. https://doi.org/10.1590/1678-69712016/administracao. v17n5p188-215

Statistics South Africa (StatsSA), 2018, Quarterly labour force survey - QLFS Q4:2018, viewed 07 February 2019, from http://www.statssa.gov.za/?p=11882

Stefanovic, I, Prokic, S. \& Rankovic, L., 2010, 'Motivational and success factors of entrepreneurs: The evidence from a developing country', Original Scientific Paper 28(2), 251-269.

Sustainable Development Consortium, 2007, Settlement implement support strategy (SIS) for land and Agrarian reform in South Africa: Synthesis document Commission on Restitution of Land and Rights in Department of Land Affairs, Pretoria, viewed n.d., from https://www.gov.za/sites/default/files/gcis document/201411/dlasynthesisreportsept2007.pdf.

Swai, E., 2014, 'Women entrepreneurs: Motives, characteristics and outturn evidence from Mzumbe award', PhD thesis, Mzumbe University, Mzumbe.

Tidd, J. \& Bessant, J.R., 2018, Managing innovation: Integrating technological, market and organizational change, John Wiley \& Sons, Hoboken, NY.

Trade and Investment Limpopo (TILL), 2006, About TIL, viewed 12 October 2018, from https://www.til.co.za/about_til.htm.

Tshabalala, N.G., 2014, 'Crime and unemployment in South Africa: Revisiting an established causality: Evidence from the Kwazulu Natal province', Mediterranean Journal of Social Sciences 5(15), 519. https://doi.org/10.5901/mjss.2014.v5n15p519

Ummah, S. \& Gunapalan, S., 2012, 'Factors influencing on entrepreneurial success: An empirical study on women headed families in Ampara and Batticaloa districts in Sri Lanka', International Journal of Business, Economics and Law 1(1), 141-148.

Wang, Z., Chen, J. \& Zang, Z., 2005, 'Strategic human resources, innovation and entrepreneurship fit', International Journal of Manpower 26(6), 544-559. https:// doi.org/10.1108/01437720510625458 